\title{
Screening of papaya accessions resistant to Papaya lethal yellowing virus and capacity of Tetranychus urticae to transmit the virus
}

\author{
Marcos Fernando Basso(1), Álvaro Júlio Pereira(2), Hermano Monteiro de Barros Pereira ${ }^{(1)}$, \\ Humberto Josué de Oliveira Ramos ${ }^{(3)}$, Jorge Luiz Loyola Dantas ${ }^{(4)}$, Elizabeth Pacheco Batista Fontes ${ }^{(3)}$, \\ Eduardo Chumbinho de Andrade ${ }^{(4)}$ and Francisco Murilo Zerbini ${ }^{(1)}$
}

\begin{abstract}
(1)Universidade Federal de Viçosa (UFV), Departamento de Fitopatologia, CEP 36570-900 Viçosa, MG, Brazil. E-mail: marcosbiotec@gmail.com, hermano.pereira@ufv.br, zerbini@ufv.br (2)Universidade Estadual do Ceará, Departamento de Ciências Biológicas, CEP 62500-000 Itapipoca, CE, Brazil. E-mail: alvarojp2003@yahoo.com.br ${ }^{(3)}$ UFV, Departamento de Bioquímica eBiologia Molecular.E-mail:humramos.ufv.br@gmail.com, bbfontes@ufv.br ${ }^{(4)}$ Embrapa Mandioca e Fruticultura, Rua Embrapa, s/no, CEP 44380-000 Cruz das Almas, BA, Brazil. E-mail: jorge.loyola@embrapa.br, eduardo.andrade@embrapa.br
\end{abstract}

Abstract - The objective of this work was to produce a polyclonal antiserum against the coat protein (CP) of Papaya lethal yellowing virus (PLYV) and to determine its specificity and sensibility in the diagnosis of the virus, as well as to evaluate the genetic resistance to PLYV in papaya (Carica papaya) accessions and to investigate the capacity of the two-spotted spider mite Tetranychus urticae to acquire and transmit PLYV to the plants. Sixty-five papaya accessions were evaluated. For each accession, ten plants were mechanically inoculated using PLYV-infected plant extracts, and three plants were mock inoculated with phosphate buffer alone and used as negative controls. Ninety days after inoculation, newly-emerging systemic leaves were collected from the inoculated plants, and viral infection was diagnosed by indirect Elisa, using polyclonal antiserum sensible to the in vitro-expressed PLYV CP. Viral transmission by T. urticae was evaluated in greenhouse. The experiments were repeated twice. Polyclonal antiserum recognized the recombinant PLYV CP specifically and discriminated PLYV infection from infections caused by other plant viruses. Out of the 65 papaya accessions evaluated, 15 were considered resistant, 18 moderately resistant, and 32 susceptible. The two-spotted spider mite T. urticae was capable of acquiring PLYV, but not of transmitting it to papaya.

Index terms: Carica papaya, Elisa, genetic resistance, plant breeding, PLYV, two-spotted spider mite.

\section{Identificação de acessos de mamoeiro resistentes ao Papaya lethal yellowing virus e capacidade de Tetranychus urticae em transmitir o vírus}

\begin{abstract}
Resumo - O objetivo deste trabalho foi produzir um antissoro policlonal contra a proteína capsidial (PC) do Papaya lethal yellowing virus (PLYV) e determinar sua especificidade e sensibilidade na diagnose do vírus, bem como avaliar a resistência genética de acessos de mamoeiro (Carica papaya) ao PLYV e investigar a capacidade do ácaro rajado Tetranychus urticae em adquirir e transmitir o vírus às plantas. Foram avaliados 65 acessos de mamoeiro. Para cada acesso, dez plantas foram submetidas à inoculação mecânica com extratos de plantas infectadas com PLYV, e três plantas receberam inoculação apenas com tampão de fosfato e foram usadas como controle negativo. Noventa dias após a inoculação, novas folhas sistêmicas emergentes foram coletadas das plantas inoculadas, e a infecção viral foi diagnosticada por Elisa indireto, com uso de antissoro policlonal sensível à PC do PLYV expressa in vitro. A transmissão viral por T. urticae foi avaliada em casa de vegetação. Os experimentos foram repetidos duas vezes. O antissoro policlonal reconheceu a PC do PLYV especificamente e discriminou a infecção pelo PLYV de infecções causadas por outros vírus. Dos 65 acessos de mamoeiros avaliados, 15 foram considerados resistentes, 18 moderadamente resistentes e 32 suscetíveis. O ácaro rajado T. urticae foi capaz de adquirir o PLYV, mas não de transmiti-lo para o mamoeiro.
\end{abstract}

Termos para indexação: Carica papaya, Elisa, resistência genética, melhoramento de plantas, PLYV, ácaro rajado.

\section{Introduction}

Papaya (Carica papaya L.) produced in the Brazilian Northeast might be affected by a lethal yellowing caused by Papaya lethal yellowing virus (PLYV), a tentative member of the genus Sobemovirus (Nascimento et al., 2010). The viral infection initially manifests itself as a yellowing of the upper leaves, which progresses to more severe symptoms such as curled leaves, wilting, and senescence. In fruit, the symptoms appear as 
greenish spots that become yellow with ripening. PLYV infection is one of the most significant viral infections in this Brazilian region (Lima et al., 2013) and may cause significant losses worldwide.

PLYV has been tentatively assigned to the genus Sobemovirus (Truve \& Fargette, 2012), which is comprised by viruses with isometric particles of approximately $30 \mathrm{~nm}$ in diameter and a genome composed of one single-stranded, positive-sense RNA molecule. The PLYV genome is 4,145 nt long and is organized in four open reading frames (ORFs): ORF1, putative movement protein and silencing suppressor; ORF2a, serine protease and VPg; ORF2b, RNA-dependent RNA polymerase; and ORF3, coat protein. The coat protein $(\mathrm{CP})$ consists of 278 amino acids and has a deduced molecular weight of approximately $37 \mathrm{kDa}$ (Pereira et al., 2012).

PLYV is easily mechanically transmitted to plants of the Caricaceae family and it can also be transmitted by contaminated hands, which shows the high stability of the virus (Amaral et al., 2006; Saraiva et al., 2006). PLYV is found in contaminated soils, irrigation water, dry leaves, leaf and root debris, and on seed surface of infected fruit, but there are no reports of transmission through the seed embryo (Camarço et al., 1998; Saraiva et al., 2006; Nascimento et al., 2010). To date, no vector has been identified for this virus (Lima et al., 2013). The bugs Myzus persicae Sulz, Diabrotica bivitulla Kirke, and D. speciosa Kirke were not capable of transmitting it (Kitajima et al., 1992; Lima et al., 2001).

The two-spotted spider mite Tetranychus urticae (Arachnida: Tetranychidae) is an economic pest worldwide, which may also be capable of transmitting plant viruses (Thomas, 1969). Given the high incidence of this mite in papaya and the fact that three different types of vectors have already been reported for sobemoviruses (aphids, beetles, and a mirid) (Truve \& Fargette, 2012), it would be reasonable to test $T$. urticae capability to acquire and transmit PLYV to papaya.

To detect PLYV, the reverse transcription-polymerase chain reaction (RT-PCR) and enzyme-linked immunosorbent assay (Elisa) methods are used. Although Elisa is less sensitive than RT-PCR, it is more suitable for routine use with a large number of samples. However, it requires a high-quality antibody to achieve specificity and sensitivity. The quality of an antibody is directly related to the purity and structural integrity of the antigen. Recombinant proteins expressed in prokaryotic systems (generally Escherichia coli) are frequently used in research because they are stable, abundant, and easily purified. Due to the low genetic variability in the $\mathrm{CP}$ gene among isolates of PLYV (Daltro et al., 2012), an antiserum against the CP of a specific virus isolate may detect different isolates. Furthermore, the antiserum would constitute an important tool for papaya germplasm screening for genetic resistance to PLYV.

The only effective control measure for PLYV is the eradication of symptomatic plants. Therefore, for viral diseases, planting resistant cultivars is the most effective control method (Gómez et al., 2009). Currently, almost all the areas dedicated to commercial papaya production in Brazil are planted with only three cultivars, which are members of two groups: the Solo Group, represented by the Sunrise Solo and Improved Sunrise Solo 72/12 cultivars; and the Formosa Group, represented by the Tainung number 1 cultivar. This evidences an extremely narrow genetic base, which renders this crop much vulnerable to diseases and other stresses (Santos, 2009). Efficient and consistent detection methods and the identification of sources of resistance could contribute to reduce disease incidence and economic losses due to PLYV.

The objective of this work was to produce a polyclonal antiserum against PLYV CP and to determine its specificity and sensibility in the diagnosis of the virus, as well as to evaluate the genetic resistance to PLYV in papaya accessions and to investigate the capacity of the two-spotted spider mite T. urticae to acquire and transmit PLYV to the plants.

\section{Materials and Methods}

Standard procedures were performed to produce polyclonal antiserum against the in vitro-expressed PLYV CP (Sambrook \& Russel, 2001). Viral RNA was extracted from the leaves of infected papaya plants, displaying typical symptoms of lethal yellowing disease, using the RNeasy Plant Mini Kit (Qiagen Biotecnologia Brasil Ltda., São Paulo, SP, Brazil). The full-length CP ORF of PLYV isolate 21 (GenBank accession number JQ394925) was amplified by RT-PCR with the oligonucleotides PLYVcpBamHI (5'-GAT CGG ATC CAT GAT TTC AGC CGG TCGA-3', forward) and PLYVcpEcoRI (5'-TAC GGA 
ATT CTT ATA GGT TTA GAG CAG ATG-3', reverse), cloned into the BamHI and EcoRI site of the pRSET_A expression vector (Life Technologies do Brasil Ltda., São Paulo, SP, Brazil), and sequenced to confirm the integrity and correct orientation of the insert. For in vitro expression, the construct pRSET-CP-PLYV was transformed into the E. coli strain BL21:DE3 using a heat-shock procedure, and a single colony was grown at $37^{\circ} \mathrm{C}$ in $200 \mathrm{~mL} \mathrm{LB} /$ ampicillin until it reached an $\mathrm{OD}_{600}$ of approximately 0.5 , when the synthesis of the recombinant protein was induced with $2 \mathrm{mmol} \mathrm{L} \mathrm{L}^{-1}$ isopropyl- $\beta$-D-thiogalactopyranoside (IPTG). Six hours after induction, bacterial cells were collected by centrifugation at $5.000 \mathrm{~g}$ for $10 \mathrm{~min}$. A total protein extract was obtained by re-suspension in lysis buffer $\left(50 \mathrm{mmol} \mathrm{L}^{-1}\right.$ Tris- $\mathrm{HCl}, 100 \mathrm{mmol} \mathrm{L}^{-1} \mathrm{NaCl}$, 2 mmol L-1 EDTA, $\mathrm{pH}$ 8.0), lysozyme treatment, and sonication (Fajardo et al., 2007). The total protein extract was re-suspended in $1 \mathrm{~mL}$ of $100 \mathrm{mmol} \mathrm{L}^{-1} \mathrm{NaHCO}_{3}$, $\mathrm{pH} 9.0$, plus $0.5 \%$ SDS (w/v), and the recombinant $\mathrm{CP}$ was purified by affinity chromatography using a Ni-NTA column (Qiagen Biotecnologia Brasil Ltda., São Paulo, SP, Brazil), according to the manufacturer's instructions, under nondenaturing conditions. After dialysis in $10 \mathrm{mmol} \mathrm{L}^{-1}$ phosphate buffer, $\mathrm{pH} 7.4$, plus $0.425 \% \mathrm{NaCl}(\mathrm{w} / \mathrm{v})$, protein integrity was analyzed by SDS-Page and quantification was performed with the NanoDrop ND-1000 spectrophotometer (Thermo Fisher Scientific Brasil Instrumentos e Processo Ltda., São Paulo, SP, Brazil), according to the manufacturer's instructions. Protein identity was determined using ion trap mass spectrometry, according to Shevchenko et al. (2006).

For immunization, 250, 400, 550, 700, and $850 \mu \mathrm{g}$ of the in vitro-expressed protein were injected intramuscularly into the hind legs of two white, 40-day-old, New Zealand rabbits, at weekly intervals. The first injection was performed with complete Freund's adjuvant $(1: 1 \mathrm{v} / \mathrm{v})$, and the four remaining injections, with incomplete Freund's adjuvant $(1: 1 \mathrm{v} / \mathrm{v})$. One week after the last injection, seven weekly bleedings were carried out (25-30 $\mathrm{mL}$ per bleeding). Blood samples were incubated for 1 hour at $37^{\circ} \mathrm{C}$, followed by 2 hours at $4^{\circ} \mathrm{C}$, in order to coagulate, and then were centrifuged at $3.500 \mathrm{~g}$ for $10 \mathrm{~min}$. The supernatant (antiserum) was aliquoted and stored at $-20^{\circ} \mathrm{C}$.

The antiserum specificity against the recombinant PLYV CP was confirmed by Western blot (Fajardo et al., 2007). The specificity, sensitivity, and optimal concentration of the anti-CP serum were also evaluated using indirect Elisa, according to Almeida \& Lima (2001). The antiserum was diluted to $1: 500,1: 1,000$, 1:5,000, and 1:10,000, and tested against protein extracts from newly-emerging symptomatic papaya leaves. Samples were considered infected when the absorbance at $405 \mathrm{~nm}$ was at least twice the average value of the negative controls (extract from healthy papaya). To confirm the antiserum specificity, an additional indirect Elisa was carried out for total protein extracts from papaya plants infected with the potyvirus Papaya ringspot virus (PRSV).

Sixty-five papaya accessions were evaluated, obtained from the active germplasm bank of Embrapa Mandioca e Fruticultura, located at Cruz das Almas, in the state of Bahia, Brazil (Table 1). The experiment was conducted in greenhouse, on the campus of Universidade Federal de Viçosa, in the state of Minas Gerais, Brazil. Ten plants of each accession were inoculated in a completely randomized design, and the experiment was repeated twice. Plants with 5-8 leaves were mechanically inoculated twice (15 day interval) with PLYV isolate 21 (JQ394925). The inoculation was performed via PLYV-infected plant extract, ground in $0.05 \mathrm{~mol} \mathrm{~L}^{-1}$ sodium phosphate buffer, $\mathrm{pH} 7.5$, with $0.1 \%$ sodium sulfite in 1:2 proportions (weight of leaves per volume of buffer). The extract was rubbed on the surface of leaves previously sprinkled with aluminum oxide (600 mesh). Three plants of each accession were mock inoculated with phosphate buffer alone (no PLYV-infected plant extract), and was used as negative controls.

Ninety days after the first inoculation, newly-emerging systemic leaves (non-inoculated) were collected, and viral infection was diagnosed by indirect Elisa, initially using a polyclonal PLYV CP antiserum kindly provided by Professor José Albérsio de Araújo Lima from Universidade Federal do Ceará, and then using the antiserum produced in the present study. Samples with an absorbance value at least twice as higher than that of the negative controls (healthy plants) were considered positive for the presence of PLYV. A given accession was considered "resistant" if less than $25 \%$ of the inoculated plants were infected; "moderately resistant" if $25-50 \%$ of the inoculated plants were infected; and "susceptible" when more than $50 \%$ of the inoculated plants were infected. 
Table 1. Characteristics of the papaya (Carica papaya) accessions from the active germplasm bank of Embrapa Mandioca $\mathrm{e}$ Fruticultura, evaluated as sources of resistance to Papaya lethal yellowing virus (PLYV).

\begin{tabular}{|c|c|c|c|c|c|}
\hline Accession & Species & Common name & Original source & Origin & Classification $^{(1)}$ \\
\hline$\overline{\mathrm{CMF}} 11$ & Carica papaya & DCG4403 & Cenargen, Brasília & Costa Rica & Moderately resistant \\
\hline CMF 12 & Carica papaya & DCG5956 & Cenargen, Brasília & Malaysia & Resistant \\
\hline CMF 14 & Carica papaya & DCG5908 & Cenargen, Brasília & Malaysia & Resistant \\
\hline CMF 15 & Carica papaya & DCG5863 & Cenargen, Brasília & Malaysia & Resistant \\
\hline CMF 18 & Carica papaya & DCG4246 & Cenargen, Brasília & Taiwan & Resistant \\
\hline CMF 20 & Carica papaya & DCG4244 x 4391 & Cenargen, Brasília & Brazil & Susceptible \\
\hline CMF 21 & Carica papaya & Solsun & Cenargen, Brasília & Brazil & Moderately resistant \\
\hline CMF 22 & Carica papaya & DCG5903 - Sunrise & Cenargen, Brasília & Malaysia & Moderately resistant \\
\hline CMF 24 & Carica papaya & Conchita & EBDA, Conceição do Almeida, Bahia & Costa Rica & Moderately resistant \\
\hline CMF 26 & Carica papaya & DCG4224 & EBDA, Conceição do Almeida, Bahia & Taiwan & Resistant \\
\hline CMF 27 & Carica papaya & DCG432 & EBDA, Conceicão do Almeida, Bahia & $-(2)$ & Moderately resistant \\
\hline CMF 28 & Carica papaya & DCG439 & EBDA, Conceição do Almeida, Bahia & Costa Rica & Susceptible \\
\hline CMF 30 & Carica papaya & DCG4344 & EBDA, Conceição do Almeida, Bahia & - & Resistant \\
\hline CMF 31 & Carica papaya & DCG441 & EBDA, Conceição do Almeida, Bahia & Costa Rica & Susceptible \\
\hline CMF 33 & Carica papaya & DCG539 & EBDA, Conceição do Almeida, Bahia & - & Resistant \\
\hline CMF 36 & Carica papaya & Guinea - GoldxSel.Mexicana & EBDA, Conceição do Almeida, Bahia & Brazil & Resistant \\
\hline CMF 38 & Carica papaya & JS3 & EBDA, Conceição do Almeida, Bahia & Brazil & Moderately resistant \\
\hline CMF 44 & Carica papaya & JS21 & EBDA, Conceição do Almeida, Bahia & Brazil & Resistant \\
\hline CMF 46 & Carica papaya & S3 & EBDA, Conceição do Almeida, Bahia & Brazil & Resistant \\
\hline CMF 47 & Carica papaya & $\mathrm{S} 15$ & EBDA, Conceição do Almeida, Bahia & Brazil & Resistant \\
\hline CMF 52 & Carica papaya & Solo & EBDA, Conceição do Almeida, Bahia & Brazil & Moderately resistant \\
\hline CMF 54 & Carica papaya & PRI065 x Tailândia & EBDA, Conceição do Almeida, Bahia & Hawaii & Resistant \\
\hline CMF 56 & Carica papaya & 7212 x Maradol & EBDA, Conceição do Almeida, Bahia & Brazil & Moderately resistant \\
\hline CMF 59 & Carica papaya & Malaysian Yellow 422 & EBDA, Conceição do Almeida, Bahia & Hawaii & Susceptible \\
\hline CMF 60 & Carica papaya & Sunrise Cross 2 & EBDA, Conceição do Almeida, Bahia & Hawaii & Moderately resistant \\
\hline CMF 65 & Carica papaya & K77xJSI2 & EBDA, Conceição do Almeida, Bahia & Brazil & Moderately resistant \\
\hline CMF 72 & Carica papaya & FERREIRA 87 & EBDA, Conceição do Almeida, Bahia & - & Susceptible \\
\hline CMF 76 & Carica papaya & MangaMourão & - & - & Moderately resistant \\
\hline CMF 82 & Carica papaya & Hortus Gold & University of Natal & South Africa & Susceptible \\
\hline CMF 88 & Carica papaya & Kapoho Purple & Hawaii (Hilo) & Hawaii & Susceptible \\
\hline CMF 92 & Carica papaya & Kapoho Green & Hawaii (Hilo) & Hawaii & Susceptible \\
\hline CMF 94 & Carica papaya & - & Cenargen, Brasília & Brazil & Susceptible \\
\hline CMF 102 & Carica papaya & - & Cruz das Almas, Bahia & Brazil & Susceptible \\
\hline CMF 108 & Carica papaya & SEED546 & - & South Africa & Moderately resistant \\
\hline CMF 114 & Carica papaya & SEED1216 & - & South Africa & Susceptible \\
\hline CMF 115 & Carica papaya & SEED1250 & - & South Africa & Susceptible \\
\hline CMF 116 & Carica papaya & SEED1291 & - & South Africa & Susceptible \\
\hline CMF 120 & Carica papaya & Faz. Caminhoá & Cruz das Almas, Bahia & Brazil & Moderately resistant \\
\hline CMF 121 & Carica papaya & - & - & - & Moderately resistant \\
\hline CMF 123 & Carica papaya & Vermelho Thai & Cenargen, Brasília & Thailand & Susceptible \\
\hline CMF 129 & Carica papaya & - & Embrapa Amazônia Ocidental, Amazonas & Brazil & Susceptible \\
\hline CMF 130 & Carica papava & - & - & - & Susceptible \\
\hline CMF 132 & Carica papaya & Seleção $\neq 2$ & Cenargen, Brasília & Hawaii & Susceptible \\
\hline CMF 142 & Carica papaya & $16 \times 17$ & 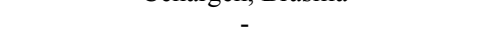 & - & Susceptible \\
\hline CMF 145 & Carica papaya & Sergipe Verde $\mathrm{x} 6$ & - & - & Susceptible \\
\hline CMF 150 & Carica papaya & Golden & Teixeira de Freitas, Bahia & Brazil & Resistant \\
\hline CMF 154 & Carica papaya & Maradol Gua & Cenargen, Brasília & Guatemala & Susceptible \\
\hline CMF 155 & Carica papaya & FRF1421 - Common papaya & Barra do Garças, Mato Grosso do Sul & Brazil & Susceptible \\
\hline CMF 164 & Jaracatia spinosa & FRF1434 Jaracatia & Antônio João, Mato Grosso do Sul & Brazil & Susceptible \\
\hline CMF 165 & Jaracatia spinosa & FRF1435 Jaracatia & Bela Vista, Mato Grosso do Sul & Brazil & Susceptible \\
\hline CMF 166 & Carica papaya & FRF1436 - Common papaya & Bela Vista, Mato Grosso do Sul & Brazil & Susceptible \\
\hline CMF 172 & Carica papaya & FRF1442 - Common papaya & Parnaíba, Mato Grosso do Sul & Brazil & Resistant \\
\hline CMF 175 & Carica papaya & FRF1445 - Common papaya & Rio Verde, Goiás & Brazil & Susceptible \\
\hline CMF 176 & Carica papava & FRF1446 - Common papaya & Rio Verde, Goiás & Brazil & Moderately resistant \\
\hline CMF 183 & Carica papaya & FRF1427 - Common papaya & Cenargen, Brasília & Brazil & Susceptible \\
\hline CMF 186 & Carica papaya & FRF1434 - Common papaya & Cenargen, Brasília & Brazil & Susceptible \\
\hline CMF 187 & Carica papaya & FRF1435 - Common papaya & Cenargen, Brasília & Brazil & Susceptible \\
\hline CMF 200 & Carica papaya & FRF1454 - Common papaya & Cenargen, Brasília & Brazil & Susceptible \\
\hline CMF 204 & Carica papaya & FRF1473 - Common papaya & Cenargen, Brasília & Brazil & Moderately resistant \\
\hline CMF 206 & Carica papaya & FRF1475 - Common papaya & Cenargen, Brasília & Brazil & Susceptible \\
\hline CMF 220 & Carica papaya & FRF1508 - Common papaya & Cenargen, Brasília & Brazil & Moderately resistant \\
\hline CMF 223 & Carica papaya & FRF1520 - Common papaya & Cenargen, Brasília & Brazil & Resistant \\
\hline CMF 230 & Carica papaya & Solo papaya - Ouromel & Porto Seguro, Bahia & Brazil & Susceptible \\
\hline CMF 234 & Carica papaya & Solo papaya - BS - Faz. SF & Teixeira Freitas, Bahia & Brazil & Moderately resistant \\
\hline CMF 235 & Carica papaya & Solo papaya - JTA & Teixeira Freitas, Bahia & Brazil & Susceptible \\
\hline
\end{tabular}

${ }^{(1)}$ The accessions were evaluated by indirect Elisa at 90 days after inoculation and considered as: resistant, $<25 \%$ of the inoculated plants were infected; moderately resistant, $25-50 \%$ of the inoculated plants were infected; and susceptible, $>50 \%$ of the inoculated plants were infected. ${ }^{(2)}$ Information not available. 
To evaluate the capacity of the two-spotted spider mite T. urticae to acquire and transmit PLYV to papaya, transmission experiments were conducted in a greenhouse using two susceptible accessions (CMF 130 and CMF 145), in a completely randomized design. The experiment was repeated twice. The mites were reared on healthy papaya plants and transferred to PLYV-infected papaya during an acquisition access period of 30 days; then, they were transferred to susceptible healthy papaya and stayed on the plants until the end of the experiment. Plants were examined for PLYV infection by indirect Elisa at 90 and 150 days after the transfer of the spider mites. The spider mites maintained in infected plants were analyzed by RT-PCR, using the PLYVcpBamHI and PLYVcpEcoRI primers, and also by indirect Elisa, using the polyclonal antiserum produced in the present study.

Viral RNA was isolated from samples comprised of either ten adult spider mites or 30 nymphs, using TRIzol Reagent (Life Technologies do Brasil Ltda., São Paulo, SP, Brazil). The cDNA was synthetized with SuperScript III Reverse Transcriptase kit (Life Technologies do Brasil Ltda., São Paulo, SP, Brazil), and PCR was performed with the GoTaq DNA Polymerase kit (Promega, Madison, WI, USA), according to the manufacturer's instructions. The amplified DNA was cloned into the pGEM-T Easy vector and sequenced. The Elisa tests were performed as described by Almeida \& Lima (2001), using 70 spider mites - adults or nymphs - processed in $200 \mu \mathrm{L}$ of sodium carbonate $50 \mathrm{mmol} \mathrm{L}^{-1}, \mathrm{pH}$ 9.6. Spider mites kept in healthy papaya were used as negative controls in both RT-PCR and Elisa assays.

\section{Results and Discussion}

The expression of the PLYV CP in E. coli BL21:DE3 resulted in an average protein yield of $17.32 \mu \mathrm{g} \mathrm{mL}-1$. Recombinant fusion protein had a molecular mass of approximately $38 \mathrm{kDa}$, which corresponds to the PLYV CP, plus $3 \mathrm{kDa}$ from amino acid residues tagged to its $\mathrm{N}$-terminus. The molecular weight and identity of the purified protein was confirmed by SDS-Page (Figure $1 \mathrm{~A}$ ) and mass spectrometry. The titer of the polyclonal antiserum was initially evaluated by Western blot analysis. The dilution of 1:1,000 resulted in high sensitivity and specificity for detecting in vitro-expressed protein and viral protein from extracts of PLYV-infected papaya (Figure 1 B). Indirect Elisa showed that the anti-CP serum at a dilution of $1: 1,000$ was specific and sensible for detecting PLYV infection, since no cross reaction was observed with protein extracts from plants infected with PRSV (Table 1).

The expression of recombinant PLYV CP in E. coli BL21:DE3 yielded enough PLYV CP to conduct the

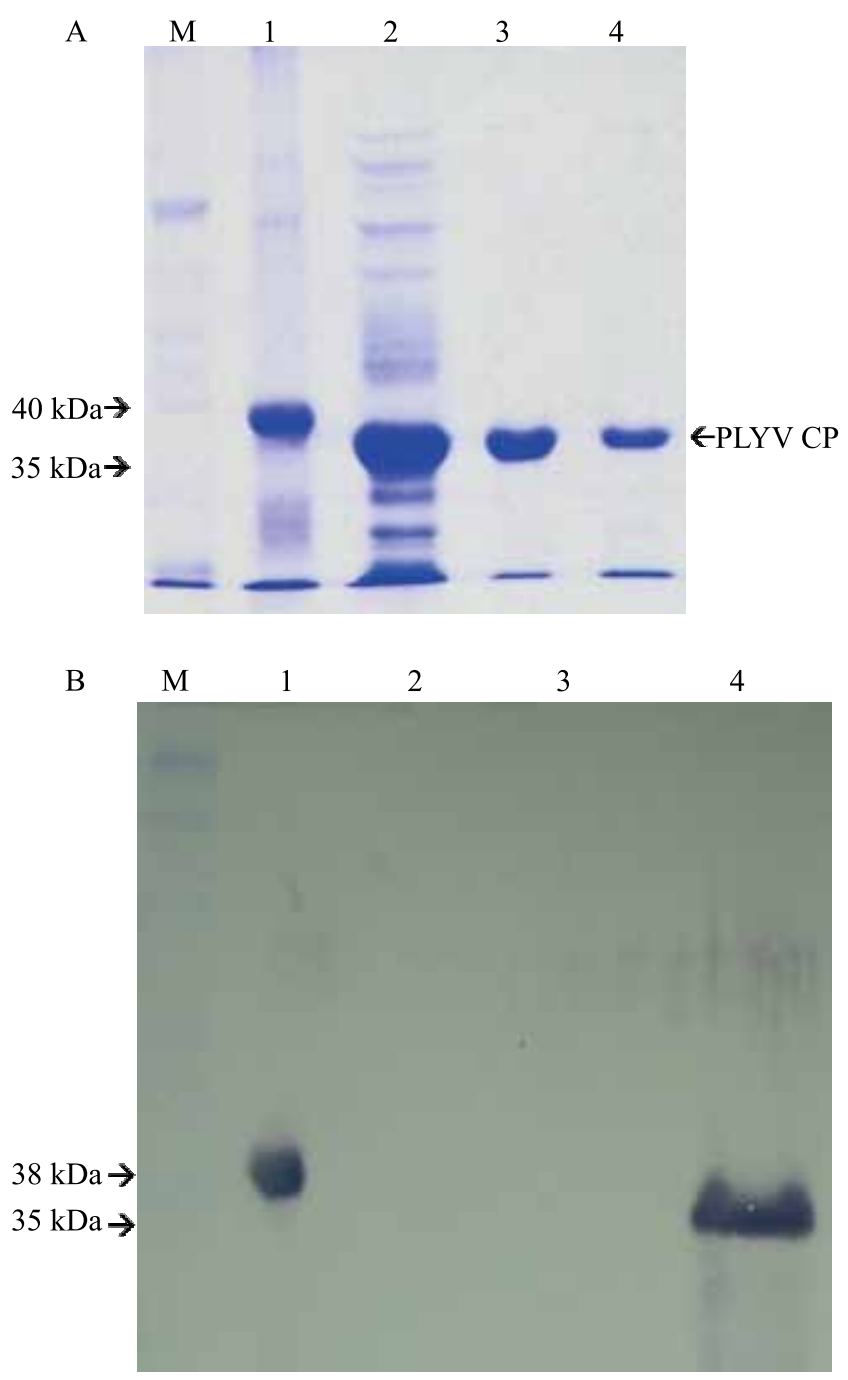

Figure 1. Expression of Papaya lethal yellowing virus (PLYV) coat protein (CP) in Escherichia coli (A): molecular weight markers in $\mathrm{kDa}(\mathrm{M}), E$. coli-produced and purified movement protein of Tomato yellow spot virus (1), total protein extract from IPTG-induced $E$. coli culture transformed with pRSET-CP-PLYV (2), purified PLYV CP (3 and 4); and Western blot analysis using the anti-PLYV CP polyclonal antiserum produced against the in vitro-expressed protein (B): PLYV CP expressed in E.coli (1), GFP expressed in E. Coli (2), total protein extract from healthy papaya (3), and total protein extract from PLYV-infected papaya (4). 
immunization of rabbits for antiserum production. The obtained results were similar to the average yields of recombinant coat proteins found for other viruses (Fajardo et al., 2007; Basso et al., 2010). Good quality antiserum is essential for the efficiency of serological detection, particularly for a low titer virus such as PLYV (Nascimento et al., 2010). The PLYV CP antiserum obtained in the present study showed sensitivity and absence of cross-reactions with other viruses or with plant extracts from healthy papaya. Similar results were found with antiserum produced from purified viral particles (Nascimento et al., 2010).

An advantage of an antiserum produced against recombinant protein expressed in E. coli is that the $E$. coli culture can be stored indefinitely at $-80^{\circ} \mathrm{C}$ and can be used to express protein for the production of a new batch of antiserum, whenever necessary. This allows not only for the production of large quantities of antiserum, but also guarantees a high degree of uniformity due to the easily replicable process of protein expression and purification. This is not the case with purified virus preparations, which require a large amount of infected leaf material and often display variable yields and degrees of purity.

Most of the accessions (32) were susceptible to PLYV (Table 2). Fifteen accessions had low infection or absence of PLYV and were, therefore, classified as resistant, whereas 18 were moderately resistant. This variation reveals high diversity within papaya germplasm, regarding resistance to PLYV. Resistant accessions, approximately $23 \%$ of the total, may constitute resistance sources to PLYV. Among them,

Table 2. Results of indirect Elisa to test polyclonal antiserum produced against the in vitro-expressed coat protein (CP) of Papaya lethal yellowing virus (PLYV).

\begin{tabular}{lccc}
\hline Sample & \multicolumn{2}{c}{$\begin{array}{c}\text { Antiserum absor- } \\
\text { bance at } 405 \mathrm{~nm}\end{array}$} & \\
\cline { 2 - 3 } & Result ${ }^{(1)}$ \\
& Rabbit 1 & Rabbit 2 & \\
\hline Buffer & 0.101 & 0.121 & Negative \\
Healthy papaya (negative control) & 0.362 & 0.491 & Negative \\
In vitro-expressed PLYV CP & 1.483 & 1.450 & Positive \\
In vitro-expressed PLYV CP & 1.745 & 1.533 & Positive \\
PLYV-infected papaya (sample 1) & 0.948 & 1.164 & Positive \\
PLYV-infected papaya (sample 2) & 0.893 & 1.040 & Positive \\
PRSV-infected papaya & 0.296 & 0.325 & Negative \\
\hline
\end{tabular}

(1)Readings performed $30 \mathrm{~min}$ after addition of substrate, with antiserum diluted to 1:1,000 (v:v) in substrate buffer. ${ }^{(2)} 0.216 \mathrm{ng} .{ }^{(3)} 0.433 \mathrm{ng}$. PRSV, Papaya ringspot virus (genus Potyvirus, family Potyviridae).
CMF 27, CMF 36, and CMF 44 are the strongest candidates, since the inoculated plants remained symptomless, with no virus detected during the entire evaluation period.

Of the 65 accessions evaluated, approximately $80 \%$ were considered moderately susceptible or susceptible to the virus. Two aspects related to this response to the lethal yellowing disease are noteworthy: firstly, the infection was not established in some plants of susceptible accessions, and some plants of resistant accessions developed symptoms, with the infection confirmed by Elisa; secondly, the proportion of accessions classified as resistant can be considered high when compared to other pathosystems. These results are probably due to genetic variability among plants of each accession and suggest that PLYV resistance has an oligo- or a polygenic inheritance. Therefore, putative resistance genes might be segregating among these plants, making some of them behave as resistant. Segregation of putative resistance genes is also the most likely explanation for the occurrence of infected plants in accessions classified as resistant. Ramos et al. (2011) suggested that the Golden cultivar consists of a fixed non-genetic type and, consequently, is subject to high rates of segregation.

Most of the searches for sources of virus resistance in accessions from germplasm banks identified a small number of resistant accessions, if any. Specifically for papaya, no resistance sources to the potyvirus PRSV, the causal agent of papaya ringspot, were reported (Magdalita et al., 1997; Dillon et al., 2005; O’Brien \& Drew, 2009). Similarly, Nascimento et al. (2012) found that all commercial varieties of squash (Cucurbita spp.) were susceptible to PRSV-W (Papaya ringspot virus, watermelon strain) and just one genotype and its endogamic progeny were resistant.

Papaya cultivars grown in Brazil are products from breeding programs conducted in other countries, which do not consider resistance to PLYV, since it occurs exclusively in Brazil (Silva et al., 2007; Nascimento et al., 2010). However, considering the restricted occurrence of lethal yellowing disease in some states of the Brazilian Northeast region, it is plausible that sources of resistance may be present in local Carica germplasm, as indicated by the results obtained in the present study.

RT-PCR and indirect Elisa using the polyclonal anti-CP serum confirmed the presence of viral genome 
or of encapsulated virus in T. urticae spider mites, showing that they are capable of acquiring the virus (Table 3 and Figure 2). However, susceptible papaya plants remained asymptomatic and tested negative for the presence of PLYV by Elisa, after exposed to the spider mite. Therefore, the two-spotted spider mite is able to acquire PLYV during feeding punctures, but is

Table 3. Results of indirect Elisa from potentially viruliferous Tetranychus urticae spider mites kept in papaya (Carica papaya) plants infected with Papaya lethal yellowing virus (PLYV).

\begin{tabular}{lcc}
\hline Sample & $\begin{array}{c}\text { Absorbance } \\
\text { at 405 nm }\end{array}$ & Result \\
\hline Phosphate buffer & 0.310 & Negative \\
Healthy papaya & 0.432 & Negative \\
T. urticae maintained in healthy papaya & 0.451 & Negative \\
PLYV-infected papaya & 1.192 & Positive \\
T. urticae maintained in PLYV-infected & 1.605 & Positive \\
papaya & & \\
\hline
\end{tabular}

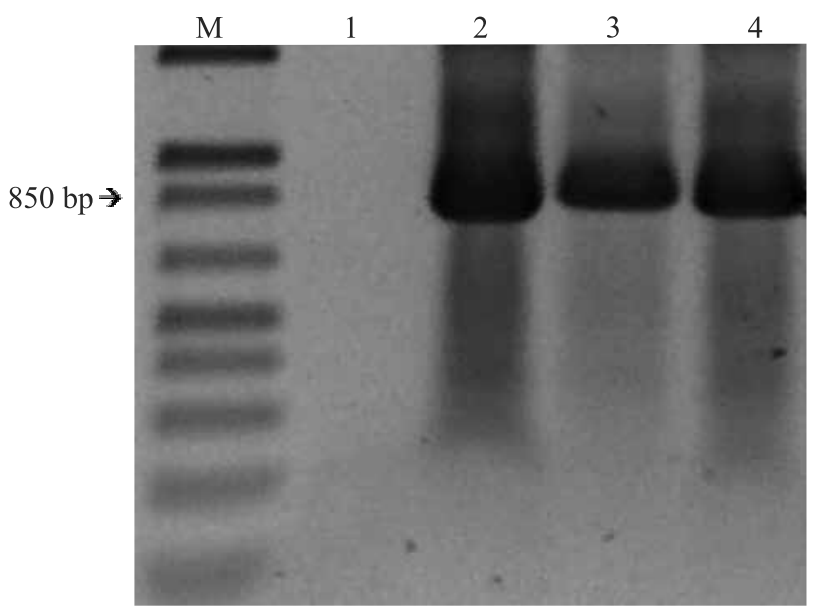

Figure 2. RT-PCR based amplification using specific primers for the coat protein (CP) gene of Papaya lethal yellowing virus (PLYV) from Tetranychus urticae spider mites collected from healthy and PLYV-infected papaya (Carica papaya). M, size marker (1Kb plus DNA ladder); 1, amplification from spider mites kept in healthy papaya; 2, amplification from PLYV RNA (positive control); 3, amplification from spider mites kept in PLYV-infected papaya (sample comprised of ten spider mites); and 4, amplification from spider mites kept in PLYV-infected papaya (sample comprised of 30 spider mites). not capable to retain or transmit the virus to papaya. Equivalent results of acquisition but no transmission were also reported by Orlob (1968) and Granillo \& Smith (1974) with five different plant viruses. Although different acquisition or inoculation periods were not tested in the present study, the long time spent for these purposes (30 days) should have been more than enough to warrant acquisition and inoculation by the arthropods.

It is likely that the retention and transmission of the virus by the vector are associated with the specificity of protein-protein interactions between the viral particles and proteins from the vector (Peng et al., 1998; Seo et al., 2010). It has been shown that the aphid M. persicae and the beetles D. bivitulla and D. speciosa are not capable to transmit PLYV to papaya (Kitajima et al., 1992; Lima et al., 2001). Therefore, the vector of PLYV remains to be identified, with the possibility that the virus may not have one.

\section{Conclusions}

1. The antiserum produced against the in vitro-expressed coat protein (CP) of Papaya lethal yellowing virus (PLYV) has high sensitivity and specificity for PLYV CP, and is able to discriminate PLYV infection from infections by other plant viruses.

2. The two-spotted spider mite Tetranychus urticae is able to acquire, but not to transmit PLYV to papaya (Carica papaya).

3. There is a high diversity within papaya germplasm, regarding resistance to PLYV.

\section{Acknowledgments}

To Fundação de Amparo à Pesquisa do Estado de Minas Gerais (Fapemig), to Coordenação de Aperfeiçoamento de Pessoal de Nível Superior (Capes), and to Conselho Nacional de Desenvolvimento Científico e Tecnológico (CNPq), for financial support; and to Instituto Nacional de Ciência e Tecnologia em Interações Planta-Praga (INCT), for support on the coordenation of the research.

\section{References}

ALMEIDA, A.M.R.; LIMA, J.A. de A. Princípios e técnicas de diagnose aplicados em fitovirologia. Londrina: Embrapa Soja; Brasília: Sociedade Brasileira de Fitopatologia, 2001. 186p. 
AMARAL, P.P.; RESENDE, R.O.; SOUZA JUNIOR, M.T. Papaya lethal yellowing virus (PLYV) infects Vasconcellea cauliflora. Fitopatologia Brasileira, v.31, p.517, 2006. DOI: 10.1590/ S0100-41582006000500014.

BASSO, M.F.; FAJARDO, T.V.M.; EIRAS, M.; AYUB, R.A.; NICKEL, O. Produção de antissoro policlonal utilizando a proteína capsidial recombinante do Rupestris stem pitting-associated virus. Ciência Rural, v.40, p.2385-2388, 2010. DOI: 10.1590/ S0103-84782010001100022.

CAMARÇO, R.F.E.A.; LIMA, J.A.A.; PIO-RIBEIRO, G. Transmissão e presença em solo do Papaya lethal yellowing virus. Fitopatologia Brasileira, v.23, p.453-458, 1998.

DALTRO, C.B.; PEREIRA, Á.J.; CASCARDO, R.S.; ALFENAS-ZERBINI, P.; BEZERRA-JUNIOR, J.E.A.; LIMA, J.A.A.; ZERBINI, F.M.; ANDRADE, E.C. Genetic variability of papaya lethal yellowing virus isolates from Ceará and Rio Grande do Norte states, Brazil. Tropical Plant Pathology, v.37, p.37-43, 2012. DOI: $10.1590 / \mathrm{S} 1982-56762012000100004$.

DILLON, S.; RAMAGE, C.; DREW, R.; ASHMORE, S. Genetic mapping of a PRSV-P resistance gene in "highland papaya" based on inheritance of RAF markers. Euphytica, v.145, p.11-23, 2005. DOI: $10.1007 / \mathrm{s} 10681-005-8361-3$.

FAJARDO, T.V.M.; BARROS, D.R.; NICKEL, O.; KUHN, G.B.; ZERBINI, F.M. Expression of Grapevine leafroll-associated virus 3 coat protein gene in Escherichia coli and production of polyclonal antibodies. Fitopatologia Brasileira, v.32, p.496-500, 2007. DOI: 10.1590/S0100-41582007000600007.

GÓMEZ, P.; RODRÍGUEZ-HERNÁNDEZ, A.M.; MOURY, B.; ARANDA, M.A. Genetic resistance for the sustainable control of plant virus diseases: breeding, mechanisms and durability. European Journal of Plant Pathology, v.125, p.1-22, 2009. DOI: 10.1007/s10658-009-9468-5.

GRANILLO, C.R.; SMITH, S.H. Tobacco and tomato ringspot viruses and their relationships with Tetranychus urticae. Phytopathology, v.64, p.494-499, 1974. DOI: 10.1094/Phyto-64-494.

KITAJIMA, E.W.; OLIVEIRA, F.C.; PINHEIRO, C.S.R.; SOARES, L.M.; PINHEIRO, K.; MADEIRA, M.C.; CHAGAS, M. Amarelo letal do mamoeiro solo no Estado do Rio Grande do Norte. Fitopatologia Brasileira, v.17, p.282-285, 1992.

LIMA, J.A.A.; NASCIMENTO, A.K.Q.; LIMA, R.C.A.; PURCIFULL, D.E. Papaya lethal yellowing virus. The Plant Health Instructor, 2013. DOI: 10.1094/PHI-I-2013-0123-01.

LIMA, R.C.A.; LIMA, J.A.A.; SOUZA JUNIOR, M.T.; PIO-RIBEIRO, G.; ANDRADE, G.P. Etiologia e estratégias de controle de viroses do mamoeiro no Brasil. Fitopatologia Brasileira, v.26, p.689-702, 2001. DOI: 10.1590/S0100-41582001000400001.

MAGDALITA, P.M.; PERSLEY, D.M.; GODWIN, I.D.; DREW, R.A.; ADKINS, S.W. Screening Carica papaya x C. cauliflora hybrids for resistance to Papaya ringspot virus type P. Plant Pathology, v.46, p.837-841, 1997. DOI: 10.1046/j.1365-3059.1997. d01-90.x.

NASCIMENTO, A.K.Q.; LIMA, J.A.A.; NASCIMENTO, A.L.L.; BESERRA JUNIOR, E.A.; PURCIFULL, D.E. Biological, physical, and molecular properties of a Papaya lethal yellowing virus isolate. Plant Disease, v.94, p.1206-1212, 2010. DOI: 10.1094/PDIS-11-09-0733.

NASCIMENTO, I.R. do; SANTOS, L.B. dos; SARMENTO, R. de A.; FIGUEIRA, A. dos R.; OLIVEIRA, G.I.S. de; AGUIAR, R.W. de S. Reação fenotípica de genótipos de abóboras ao vírus da mancha anelar do mamoeiro, estirpe melancia (Pappaya ringspot virus, strain watermelon, PRSV-W). Bioscience Journal, v.28, p.191-197, 2012. DOI: 10.1071/BT09111.

O'BRIEN, C.M.; DREW, R.A. Potential for using Vasconcellea parviflora as a bridging species in intergeneric hybridisation between $V$. pubescens and Carica papaya. Australian Journal of Botany, v.57, p.592-601, 2009. DOI: 10.1071/BT09111.

ORLOB, G.B. Relationships between Tetranychus urticae Koch and some plant viruses. Virology, v.35, p.121-133, 1968. DOI: 10.1016/0042-6822(68)90312-7.

PENG, Y.H.; KADOURY, D.; GAL-ON, A.; HUET, H.; WANG, Y.; RACCAH, B. Mutations in the HC-Pro gene of Zucchini yellow mosaic potyvirus: effects on aphid transmission and binding to purified virions. Journal of General Virology, v.79, p.897-904, 1998.

PEREIRA, A.J.; ALFENAS-ZERBINI, P.; CASCARDO, R.S.; ANDRADE, E.C.; ZERBINI, F.M. Analysis of the full-length genome sequence of Papaya lethal yellowing virus (PLYV), determined by deep sequencing, confirms its classification in the genus Sobemovirus. Archives of Virology, v.157, p.2009-2011, 2012. DOI: $10.1007 / \mathrm{s} 00705-012-1384-x$.

RAMOS, H.C.C.; PEREIRA, M.G.; SILVA, F.F. da; VIANA, A.P.; FERREGUETTI, G.A. Seasonal and genetic influences on sex expression in a backcrossed segregating papaya population. Crop Breeding and Applied Biotechnology, v.11, p.97-105, 2011. DOI: 10.1590/S1984-70332011000200001.

SAMBROOK, J.; RUSSEL, D.W. Molecular cloning: a laboratory manual. $3^{\text {rd }}$ ed. New York: Cold Spring Harbor Laboratory, 2001. $3 \mathrm{v}$. Irregular pagination.

SANTOS, V.J. Avaliação de resistência de genótipos de mamoeiro a Asperisporium caricae. 2009. 57p. Dissertação (Mestrado) - Universidade Federal do Recôncavo da Bahia, Cruz das Almas.

SARAIVA, A.C.M.; PAIVA, W.O. de; RABELO FILHO, F.A.C.; LIMA, J.A.A. Transmissão por mãos contaminadas e ausência de transmissão embrionária do vírus do amarelo letal do mamoeiro. Fitopatologia Brasileira, v.31, p.79-83, 2006. DOI: 10.1590/ S0100-41582006000100014.

SEO, J.K.; KANG, S.H.; SEO, B.Y.; JUNG, J.K.; KIM, K.H. Mutational analysis of interaction between coat protein and helper component-proteinase of Soybean mosaic virus involved in aphid transmission. Molecular Plant Pathology, v.11, p.265-276, 2010. DOI: $10.1111 /$ j.1364-3703.2009.00603.x

SHEVCHENKO, A.; TOMAS, H.; HAVLIS, J.; OLSEN, J.V.; MANN, M. In gel digestion for mass spectrometric characterization of proteins and proteomes. Nature Protocols, v.1, p.2856-2860, 2006. DOI: $10.1038 /$ nprot.2006.468.

SILVA, J.A.T. da; RASHID, Z.; NHUT, D.T.; SIVAKUMAR, D.; GERA, A.; SOUZA JÚNIOR, M.T.; TENNANT, P.F. Papaya 
(Carica papaya L.) biology and biotechnology. Tree and Forestry Science and Biotechnology, v.1, p.47-73, 2007.

THOMAS, C.E. Transmission of Tobacco ringspot virus by Tetranychus sp. Phytopathology, v.59, p.633-636, 1969.
TRUVE, E.; FARGETTE, D. Genus Sobemovirus. In: KING, A.M.Q.; ADAMS, M.J.; CARSTENS, E.B.; LEFKOWITZ, E.J. (Ed.). Virus taxonomy: ninth report of the International Committee on Taxonomy of Viruses. London: Elsevier, 2012. p.1185-1189.

Received on June 11, 2014 and accepted on January 23, 2015 